\title{
Study on Ecotourism Development in Kapota Island Wakatobi Regency, Southeast Sulawesi Province
}

\author{
Wijaya $^{1}$ and Janianton Damanik ${ }^{2}$ \\ ${ }^{1}$ Researcher at the Center for Tourism Studies, UGM \\ ${ }^{2}$ Senior Researcher at the Center for Tourism Studies, UGM \\ Corresponding Author: djaypuspar@ugm.ac.id
}

\begin{abstract}
ARTICLE INFO
Received

3 September 2020

Accepted

18 September 2020

Available online

30 September 2020
\end{abstract}

ABSTRACT

The current paper aims to identify the distribution of ecotourism attractions, identify the strengths, weaknesses, opportunities, and threats of ecotourism development, as well as formulate appropriate development strategies. Qualitative descriptive analysis was employed by relying on various methodologies including direct observation, unstructured interview, focus group discussion, and documentation study. It was found that Kapota Island possesses tremendous ecotourism resources and potentials due to its abundant biodiversity, such as coral reefs, mangroves, seagrass meadows, beaches, dive spots, cave, lake, landscapes, customary and traditional culture, as well as historical heritages. The island's diversity and uniqueness remain pristine/maintained due to the support given by the Wakatobi National Park Office (Balai Taman Nasional Wakatobi - TNW), customary institutions, and local communities. Accordingly, future development strategies include: (a) integration in the development of ecotourism destinations, local island based industry, collaborative marketing through digital tourism and organization of local operators; (b) orientation towards community based ecotourism to strengthen empowerment and participation of local communities; (c) capacity building of ecotourism actors and operators (tourism awareness group, Kapota customary institution, and Village Owned Enterprise administrators); and (d) increase of collaborative capacity among stakeholders.

Keywords: Conservation, Development, Ecotourism, Kapota Island 


\section{INTRODUCTION}

The government's attention to take advantage of Indonesia's ecotourism continues to rise due to its immense potentials and the existence of 54 national parks (Ministry of Environment and Forestry - KLHK, 2019). Most ecotourism destinations are located in conservation areas that not only have biodiversity potential, but natural beauty potential as well (KLHK, 2019).

Data from KLHK (2019) shows that the total of conservation land areas in Indonesia has currently reached 27.134 million hectares, which are distributed into 554 units of conservation areas. These conservation areas are accordingly distributed and specified as follows: (a) strict nature reserve 16\%; (b) wildlife reserve 18\%; (c) nature recreation park 3\%; (d) hunting park 1\%; (e) grand forest park $1 \%$; (f) national park 60\%; and (g) nature reserve/nature conservation area $1 \%$.

Facts indicate that foreign tourist visits to conservation areas continue to positively increase. During the 2015-2019 period, as many as 2.059 million foreign tourists were recorded to have visited conservation areas, wherein nearly $20 \%$ of them visited in 2019. Komodo National Park recorded the highest number of visitors in 2019 at 144,073 visitors. The average foreign tourist visit to conservation areas was at 411,689 visitors per annum, with a growth rate of $13.84 \%$ annually in the last 5 years (Directorate General of Natural Resources and Ecosystem Conservation, KLHK, 2019).

The trend of domestic tourist visits to conservation areas also continue to rise. During the 2015-2019 period, as many as 31.866 million domestic tourists had visited various conservation areas (KLHK, 2019). In 2019, as many as 7.464 million domestic visitors were recorded, which is an increase of $7.88 \%$ or 544,920 visitors compared to the previous year. It is assumed that the attraction of natural potentials with its immense biodiversity had been one of the determining factors in the increase of visitors.

Domestic tourist visits to conservation areas can serve as a huge asset in the development of ecotourism and nature tourism throughout Indonesia, since the number of domestic tourists has experienced an upsurge in the last 3 years. Tangkuban Perahu Nature Recreation Park, West Java ranked as the most visited in 2019 with as many as 913,641 visitors due to its easy access and proximity to the tourists' places of origin. By correlating these visits with the amount of Non-Tax State Revenue (Pendapatan Nasional Bukan Pajak - PNBP), the total contribution of ecotourism in 2019 is 
calculated to have reached IDR 169.555 billion (KLHK, 2019).

One of the conservation and ecotourism areas in Southeast Sulawesi Province is the Island of Kapota in Wakatobi National Park (WNP). WNP is included as a part of the world's coral triangle (WWF, 2017) and one of Indonesia's 54 national parks (KLHK, 2019). These islands function as a habitat to over 590 species of fish and 396 types of coral reefs with exceedingly high value in conserving the marine ecosystem. Such abundant biodiversity has consequently led to UNESCO establishing the national park as one of the world's biosphere reserve in 2012 (Muhtadi, 2012).

The park is a marine protected area that consists of four main islands, namely Wangi-Wangi Island, Kaledupa Island, Tomia Island, and Binongko Island with 97\% marine area and merely 3\% land area. In addition to the four major islands, there are smaller inhabited and uninhabited islands. WWF took stock of the number of islands in the area in 2006 and identified as many as 22 islands being included in the WNP area, including the Island of Kapota (Sumarno, 2016).

Governmental Regulation No. 50 Year 2011 concerning the National Tourism Master Plan places Wakatobi as one of the National Tourism Strategic Areas and one of the 10 National Priority http://ojs.unud.ac.id/index.php/eot
Tourism Destinations. Such recognition serves as a strong and strategic institutional framework to create a tourism development plan on the islands. In tune with the above, the Wakatobi Regency Tourism Master Plan (2015) asserts Kapota as one of the strategic Regional Tourism Development Areas under the theme of ecotourism and conservation.

The environment of Kapota Island remains natural along with its coastal village areas and various attractions for marine ecotourism activities, which are considered to be of utmost excellence due to its rich biodiversity and lush natural resources. For the purpose of integrated development, it can serve as a single ecotourism destination cluster coupled with Hoga Island and Onemobaa Island, which have been more frequented by foreign tourists.

Nonetheless, based on observations in the field, a number of fundamental issues were found in the context of ecotourism destination development. Studies pertaining to potentials, identification of challenges, opportunities, and threats of development, lack of amenities, basic infrastructure, and even the relatively limited quality of human resources. A previous study found that potential conflict in the management of the island is quite resilient (Sari, 2017) and it needs to be resolved. Consequently, tourism activities 
in the area remained relatively stagnant and surrounding communities have yet to reap ample benefit from such activities.

The distribution of attraction sites or spots, their strengths, weaknesses, opportunities, and threats when developing are issues that need to be identified to begin development of these attractions. The lush natural resources potential (diversity of coral reefs and types of marine biotas, particularly fish, in the Islands of Wakatobi rank among the highest in the world Supriatna, 2008) is only one of the strengths the island has. However, there is no shortage of threats and weaknesses brought about by residential activities on land and fishing models that are not in line with conservation purposes (Yulius, et al., 2015). By having a map that outlines the distribution of these sites, development strategies that relate to the conditions of these tourist attraction spots, their strengths, weaknesses, opportunities, and threats may subsequently be formulated.

The main objective of the current paper is to: (1) identify the distribution of ecotourism attractions; (2) identify strengths, weaknesses, opportunities/ chances, and threats in ecotourism development; and (3) formulate appropriate development strategies by referring to the SWOT analysis results.

http://ojs.unud.ac.id/index.php/eot

\section{LITERATURE REVIEW}

The term ecotourism emerged at the end of the 1980s as a direct result of worldwide reaction and recognition of global ecological and sustainable practices (Diamantis, 1999). Historically speaking, the term ecotourism was adopted to illustrate a phenomenon of nature tourism (Wallace \& Pierce, 1996). In more detail, ecotourism refers to a concept or philosophy capable of guiding nature-based tourism management and planning (Stein, 2004). Since the beginning, ecotourism has progressed consistently and extensively. As a result, ecotourism is considered as the largest and fastest growing subcomponent in the tourism industry (Dowling \& Fennell, 2003; Hawkins \& Lamoureux, 2001; WTTC, 2004).

In general, scholars and practitioners often cite the following two definitions of ecotourism. The International Ecotourism Society (2005) defines ecotourism as a form of responsible travel to natural areas that conserves the environment and improves the wellbeing of local people. Ceballos-Lascurain and The World Conservation Union (1996) state that ecotourism is environmentally responsible travel and visitation to relatively undisturbed natural areas, in order to enjoy, study, and appreciate nature and any accompanying cultural features 
both past and present, that promotes conservation, has low negative visitor impact, and provides for beneficially active socio-economic involvement of local populations. These definitions are asserted by Western (1997); Arida, et al. (2014) stating that ecotourism refers to tourism activities that are responsible towards natural conservation. Ecotourism must be able to create and satisfy the desire of nature by way of conserving, preserving the ecology, and involving the active participation of tourists in every aspects of development.

The responsibility and conservation aspects are reemphasized by Damanik \& Weber (2016) by defining ecotourism as nature-based tourism activities that are sustainable, managed distinctively, have a positive impact on the environment, locally oriented, non-consumptive, and focus on experiences as well as education about nature. Essentially, ecotourism refers to travel and visitation to natural areas with responsibility towards the natural environment. The travel is aimed at enjoying and appreciating nature, and it is managed based on local principles for conservation and educational purposes that involve local communities and all the cultural norms they possess (Arida, et al., 2014). Ultimately, an authentic environment is always more appealing to visitors than an artificial one (Wahab, 1989).

Thus, ecotourism is one of the forms of special tourism activities that is distinguished from mass tourism. The special interest feature is most prominent, and seeking quality experience in a pristine natural environment during a visitation is given precedence to features that expose hedonistic proclivities. In addition, economic contribution to environmental conservation and local communities by creating small and medium enterprises tend to be more dominant (Fandeli \& Mukhlison, 2000; Salazar, 2007). In a more observable reality, the characteristics of ecotourism product and market are educational and small-scale, respectively (Damanik \& Weber, 2006).

In relation to this, from (cited by Damanik \& Weber, 2006) composed three more operational basic concepts for ecotourism. First, outdoor travel in natural areas that does not lead to environmental degradation. In ecotourism activities, people commonly use energy saving power sources such as solar power, wood constructions, recycled materials, and water springs. Second, ecotourism activities prioritize the use of transportation facilities created and managed by communities. In principle, existing accommodations are not an extension of international hotel chains and food dishes e-ISSN: 2407-392X. p-ISSN: 2541-0857 
offered are not made using imported ingredients but locally based products instead. There need to be benefits for local communities so that ecotourism must function as a potential instrument to improve social behaviors for environmental conservation purposes (Buckley, 2003). Third, this kind of tourism travel pays significant attention to the natural environment and local culture. Visitors normally learn a lot from local communities about culture and nature, and not be patronizing them instead.

The context of locally based products is heavily emphasized in the development of ecotourism due to its principle of highlighting local features, particularly the empowerment of local communities. This includes labor, basic infrastructural improvements (Scheyvens, 1999), food ingredients, construction materials, and even the use of local currency (Panos Media Briefing, 1995). Hirotsune (2011) affirms there are three interconnected keywords in ecotourism, namely: conservation of nature and culture, contribution of benefits to local residents, and development opportunities through ecotourism.

The emphasis on the locality aspect is inseparable from the idea of neopopulism that has been developing in the last few decades. Neo-populism is oriented toward placing the entire development http://ojs.unud.ac.id/index.php/eot activities at the community level and associating them with the conservation of natural resources (Butcher, 2007). The idea criticizes and offers a new concept to the development approach that is oriented toward the exploitation of natural resources that threatens their sustainability and more inclined to pay little attention to the active role of local residents. The features mentioned in the later are most likely attached to mass tourism (Marzouki, et al., 2012). In the context of ecotourism, the elementary concept proposed involves protection of the environment, utilization of local facilities, significant attention and orientation to local culture and environment (Arida and Rohman, 2019).

Ecotourism can be considered as a development activity that involves a wide range of stakeholders. The local community holds a central position as any changes that occur in the ecotourism area directly affects their life and livelihood (Fennel, 2002; Khalid, et al., 2019). The local government consisting of various bureaucratic entities, business actors or investors, and the visitors themselves have varying interests that may subsequently create misinterpretations about the context of ecotourism development (Butcher, 2007). Eusebio et al. (2018) found, among others, that the intensity of visitors' relationship with local communities and the location they visit leads to a positive public 
perception regarding ecotourism development.

Accordingly, the development of ecotourism potential in a region needs to be based upon a critical assessment of all the advantages and disadvantages that its existing elements have. Rich natural resources do indeed serve as a prominent basis of development in the region, but the optimal role of investors or the private sector can accelerate achievement of ecotourism development results (Snyman, 2017). In terms of supporting capacity, the aspect of site distribution is crucial so that ecotourism activities can reduce negative impacts and enhance visitor satisfaction (Sadikin et al., 2017). This implies that development of ecotourism potential requires synchronization between various advantages and limited existing resources.

Nasrun (2016) found that the ecotourism management model in Wakatobi had been carried out in three stages, namely: (1) Wakatobi National Park established the Banakawa Forestry and Rural Extension Center (Sentra Penyuluhan Kehutanan Perdesaan SPKP) to identify and map out ecotourism potentials, and empower local communities; (2) The Ministry of Tourism and Wakatobi Regional Tourism Office collaborated with local organizations to prepare facilities and infrastructure that support ecotourism activities and empower http://ojs.unud.ac.id/index.php/eot local communities; (3) Wakatobi National Park, the regional government, and local communities jointly established a Tourism Awareness Group (Kelompok Sadar Wisata - Pokdarwis) as an institutional umbrella that is expected to be capable of running their ecotourism management practices properly.

Community engagement in ecotourism management is considered low throughout all stages of development. In the planning stage, the total average of community engagement was only at 4.65 (on a scale of 100), while the implementation stage was at 11.35 , and the monitoring stage at 3.85. Such low community engagement was influenced by several factors such as lack of information disclosure relating to ecotourism development, weak coordination and communication among ecotourism stakeholders, minimum public understanding about ecotourism, and existing dynamics of local politics.

\section{METHODS}

Kapota Island, Wakatobi Regency was selected as the location for the current study, which employed the qualitative descriptive method. The location was chosen based on the ecotourism resources available on the island, namely its rich biodiversity. Rafika (2011) found various 
tourism destinations that include physicalbiological elements, historical heritages, arts, culinary delight, and handicrafts. These destinations are supported by seven connecting pathways, which consist of six terrestrial paths and one aquatic path. The use of the qualitative method is deemed appropriate to elaborate the status of a collection of people, subjects, a set of conditions, through systems or even current events with the purpose of creating a systematic illustration or description, and relationship among the examined phenomena (Nazir, 2011). Ecotourism correlates with people and the environment along with all the impacts that relationship between the two induces.

Field research was conducted twice in April and June of 2018 in order to obtain a more comprehensive description about the subject of study. Before conducting the field survey, data from various documents published by Statistics Indonesia (BPS), Wakatobi Regional Government, Ministry of Village, Development of Disadvantaged Regions, and Transmigration (Kemendesa), and the internet were collected to acquire a general outline of the region. Nonparticipant observation was employed on ecotourism potentials (beaches, craft activities, modes of transport, tourists, and so forth) during the field survey. In-depth interviews were conducted to obtain data from residents, business actors, NGOs, http://ojs.unud.ac.id/index.php/eot community figures, and local government officials with varying time and duration. Focus group discussion was purposely selected as a method since it allows researchers to gather more abundant data than those collected from any other method (Afiyanti, 2008, Nyumba, et al., 2018).

SWOT analysis was chosen since the current study is a preliminary step to drafting a strategic plan. It is used to identify and examine existing resources internally and externally, their patterns and tendencies that may have either positive or negative impacts on a business entity (Namugenyia, et al., 2019), including regional government unit. SWOT analysis provides a clearer outline on how the strategies for future ecotourism development on Kapota Island should be.

\section{RESULTS AND DISCUSSION}

\section{Distribution of Ecotourism Attraction}

Generally, there are three factors that keep the island relatively better preserved from rapid environmental degradation. First, the local community remains reluctant to turn the area into a conventional tourism site, with constructions of hotels, resorts, and other facilities. This is due to the strong role that Kapota customary institution has in controlling the land. Most of the areas in and around the island are included as e-ISSN: 2407-392X. p-ISSN: 2541-0857 
customary land that cannot easily change function, subsequently resulting in a relatively well maintained traditional, cultural, and natural authenticity. Second, the island is located within the marine protected area of WNP established by the Ministry of Environment and Forestry, which consequently allows it to maintain a strong formal legal authority for conserving its cultural and natural assets.

Third, monitoring and support provided by international non-government organizations to maintain the national park conservation area. The position of the island, which is in close proximity to the regency's capital, surely pose both advantages and challenges to regional development. The challenges include rather sensitive environmental issues, which continue to be scrutinized by ecotourism market on both national and global scales. Despite the existing legal prohibition of extractive industrial activities, threats of environmental degradation continue to rise from economic activities, including tourism activities that are not based upon sensitivity toward marine resources. Domestic wastes coming from the island and outside of it are also among one of those challenges.

When ecotourism destination management is applied as a basis, these challenges will become great opportunities to develop the island area. The basic asset of attraction is already available in the form http://ojs.unud.ac.id/index.php/eot of abundance in natural resources, culture, arts, tradition, and history. The condition of the shoreline that runs along the island is characterized by beautiful coastal landscapes filled with healthy sea corals and clean, unpolluted sea waters. In addition, there are 20 snorkeling and diving spots located around the island that visitors can enjoy (WWF, 2017). Several agricultural, forestry, and fishery potentials may also be utilized to support culinary tourism and various handicrafts, including local cultural rituals that continue to be maintained to this day.

Kapota considers ecotourism as a potential product of excellence-supported by crafts. Ecotourism attractions are quite varied and based on flora and fauna, natural lake, natural cave, spring water, beaches, arts and culture, as well as historical heritages. There are as many as 16 flora species and 23 fauna species that can attract visitors. Other biophysical attractions, such as Tailaronto'oge Lake, Dewata Cave, Oa Wolio \& Batu Sahu'u Beaches, and Kolowowa Beach, add to the diversity of these potential attractions (Table 1). 
Table 1. Ecotourism Attractions in Kapota Island

\begin{tabular}{|c|c|c|c|c|}
\hline Flora & Fauna & $\begin{array}{l}\text { Beaches, Diving } \\
\text { Spots, Lake, and } \\
\text { Cave }\end{array}$ & $\begin{array}{l}\text { Historical Sites } \\
\text { and Culture }\end{array}$ & $\begin{array}{c}\text { Crafts and } \\
\text { Culinary Treats }\end{array}$ \\
\hline $\begin{array}{l}\text { - } 16 \text { flora species } \\
\text { (bamboo, } \\
\text { orchid, } \\
\text { moringa, } \\
\text { coconut, } \\
\text { morinda, } \\
\text { mangrove, sea } \\
\text { grass, coral } \\
\text { reefs) } \\
7 \text { species of sea } \\
\text { grass. } \\
25 \text { species of } \\
\text { coral reefs-23 } \\
\text { species } \\
\text { categorized as } \\
\text { hard coral } \\
\text { (Acropora) and } \\
2 \text { species } \\
\text { categorized as } \\
\text { soft coral (non } \\
\text { Acropora) }\end{array}$ & $\begin{array}{l}23 \text { bird } \\
\text { species, } 2 \\
\text { mammal } \\
\text { species, } 3 \\
\text { reptile } \\
\text { species and } \\
\text { butterflies) }\end{array}$ & $\begin{array}{l}\text { - } \text { Around Wangi- } \\
\text { Wangi and } \\
\text { Kapota reefs, as } \\
\text { many as } 20 \\
\text { diving spots are } \\
\text { recorded } \\
\text { - Tailoronto'oge } \\
\text { Lake } \\
\text { - Kolowowa } \\
\text { Beach } \\
\text { - Oa Wolio and } \\
\text { Watu Suhu'u } \\
\text { Beach } \\
\text { - Osuno Beach } \\
\text { - Kampa Beach } \\
\text { - Timur Beach } \\
\text { - Dewata Cave } \\
\text { - Bats) } \\
\text { Kolowowa } \\
\text { - Spring } \\
\text { Dolphin } \\
\text { attractions }\end{array}$ & $\begin{array}{l}\text { - Katiama } \\
\text { Fort } \\
\text { - Togo } \\
\text { Molengo } \\
\text { Old Town } \\
\text { - Banakawa } \\
\text { Rock } \\
\text { - Sacred sites, } \\
\text { Saru'sarua } \\
\text { (place for } \\
\text { ancestral } \\
\text { spirits of } \\
\text { Kapota } \\
\text { community), } \\
\text { Laudina, } \\
\text { Watululu, } \\
\text { and Watu } \\
\text { ndengu- } \\
\text { ndengu } \\
\text { - Kolo and } \\
\text { Kapota } \\
\text { Tourism } \\
\text { Village }\end{array}$ & $\begin{array}{l}\text { - Arts of } \\
\text { bamboo } \\
\text { weaving and } \\
\text { Leja sarong } \\
\text { weave } \\
\text { - Traditional } \\
\text { dance } \\
\text { - Customary } \\
\text { celebrations } \\
\text { called Karia } \\
\text { (circumcisio } \\
\text { n process for } \\
\text { boys), } \\
\text { somboa } \\
\text { (seclusion } \\
\text { ceremony } \\
\text { for girls } \\
\text { reaching a } \\
\text { matured } \\
\text { age), and } \\
\text { kansoda'a } \\
\text { (closing } \\
\text { ceremony } \\
\text { for the entire } \\
\text { series of } \\
\text { events) } \\
\text { Kabuenga } \\
\text { Celebration } \\
\text { (ayunan): a } \\
\text { matchmakin } \\
\text { g forum. } \\
\text { Culinary } \\
\text { dish: } \\
\text { kasuami }\end{array}$ \\
\hline
\end{tabular}

Source: RPKP Wakatobi Regency, 2018

Numerous ecotourism attractions are distributed throughout North Kapota Village (15 sites), Kapota Village (8 sites), Kabita Togo Village (3 sites), Kabita Village (6 sites), and Kolo Tourism Village (3 sites). The characteristics of these http://ojs.unud.ac.id/index.php/eot villages relatively vary and they are in need of much organization.

Thus, in order to develop the area, these ecotourism attractions need to be supported by availability of tourism facilities, particularly amenities to meet e-ISSN: 2407-392X. p-ISSN: 2541-0857 
visitors' needs. In further detail, the conditions of existing facilities are described as follows.

(a) Standard accommodation facilities are still unavailable as of current, and consequently visitors' accommodation needs are merely fulfilled by local residential house owners on a limited scale. Kapota to date has been developed as a supplementary tourist attraction spot for the town of Wanci, which renders its potential in providing facilities to become relatively disadvantaged. Through the provision of limited assistance by Pokdarwis, several residential homes have begun to be prepared as embryonic homestays along with facilities and services that are still rudimentary (Interview with Head of Greater Kapota Pokdarwis, 2018).

(b) The opportunity for culinary businesses to operate is actually available, but people have not invested in it as a permanent business. Restaurants remain unavailable on the island. It is commonplace for visitors who happen to drop by the island to ask for assistance from local residents to provide them with food or they may bring their own.

(c) Availability of information, signposts, locations, and translations are essential elements for tourists, and these are http://ojs.unud.ac.id/index.php/eot exceedingly lacking on the island. As an example, there is only limited information provided in and around the lake and fort areas, so there is no knowledge shared or acquired during visitation to these areas. The existing information board has also begun to deteriorate due to lack of maintenance. There are a few exceptions, wherein some supporting tourism facilities have been provided in Tailaronto'oge Lake, such as a multipurpose building, gazebo, toilet, and footpath. However, travelers on foot need to be cautious since the condition of the wooden bridge on the lake side is unsafe. Some parts of the bridge are broken or holey, which may endanger visitors. The crucial point in this case is proper maintenance of facilities that have been constructed through either government, private, or community funding. Accordingly, facilities need to be maintained thoroughly for the sake of the island's sustainability.

Another facility that support ecotourism development is transportation that connects visitors from, to, and during their stay at the destination site, be it through land, sea, or air. These transportation accesses not only deal with the aspect of quantity, but quality, punctuality, comfort, and safety as well (Damanik \& Weber, 2006). Transportation 
connectivity facility on the island is provided in the form of a harborresidents' main access to go in and out of Kapota Island. The harbor connects the town of Wanci and Kapota, and it is a vital facility for tourism activities and economic activities of people in general. The town remains lively with activities of residents embarking and disembarking the boats (called "jonson" in the local vernacular). It is also an interesting spot where people can view the town of Wanci across the island.

Nonetheless, there are several factors that do not support visitors' needs in the area. First, tourists are unable to find standard gift shops or restaurants. It is difficult to spend a night and stay over on the island, let alone for several nights, since there is also a risk of not being able to get proper meals. Second, there is no appealing spot that can be set as a place for visitors to take pictures at. As the main gateway to the island, facilities that can provide positive first impressions to visitors should be made available.

\section{SWOT Analysis of Ecotourism Development}

a. Strengths

Strengths are indicated, among others, by the support that the Wakatobi National Park Office and Kapota customary institution have continued to provide. The National Park Office considers ecotourism http://ojs.unud.ac.id/index.php/eot as one of the strategies to conserve natural resources. Support is also given by the regional government concerning ecotourism development of Kapota Island as explicitly stipulated in official documents, namely the Regional Spatial Plan (RTRW) for the 2012-2032 period, Regional Mid-Term Development Plan (RPJMD) for the 2016-2021 period, and the Regional Tourism Development Master Plan (Ripparda) for the 2016-2026 period.

Given the strengths described in the above passage, the Kapota Island area is considered to have the opportunity of being developed into an ecotourism destination in line with ecotourism principles. These principles, among others, include: (a) conservation principle; (b) local community engagement principle; (c) economic principle (by acquiring direct financial benefits for conservation purposes through contributions or extra expenses from visitors); (d) educational principle (by offering experiences and knowledge); and (e) tourism principle (by creating a sense of safety and comfort, as well as provide satisfaction along with valuable experiences to visitors) (Suhandi, 2020).

\section{b. Weaknesses}

Ecotourism requires very basic facilities and infrastructure to make it easier for tourists to engage in their activities. Factually speaking, the current conditions 
of the tourism infrastructure and facilities are still insufficient. This is the main weakness. The quantity and quality of exceedingly limited facilities are apparent from the availability (or lack) of restaurants, homestay, road access to tourism sites, as well as equipment for snorkeling and scuba diving on the island. As an example, out of the hundreds of residential houses, only eight met the minimum standards required for a homestay. Meanwhile, some of the insufficient infrastructure observed included public washing, bathing, and toilet facilities (MCK), tourist transportation in the area, parking area, clean water, and electricity. These limited conditions have rendered Kapota underprovided to facilitate the basic needs of tourists.

Furthermore, a classic weakness is the operators' lack of budget and human resource capacity. Although a basic plan is available, its implementation is hampered by limited fund. Such embryonic ecotourism activities merely depend on sheer natural attractions without any packaging made based on a well-defined and measured program. If a tourist were to arrive, they would not find any series of tourism activities with a description about their type, frequency, and duration. It can be said that nature's abundance has marked the island as an ecotourism attraction. Nevertheless, how ecotourism activities http://ojs.unud.ac.id/index.php/eot should be carried out in the area does not seem to be well designed as of yet.

Availability of human resources to manage ecotourism attractions is also limited in both quantity and quality. The current study was unable to find any local tourism activist with a professional background on ecotourism and conservation. This tends to consequently undermine the crucial role that ecotourism holds as one of the movers of island area conservation and economy, since ecotourism actually plays a key role in the region. Suhandi (2020) asserts that ecotourism maintains four roles. First, ecotourism creates businesses that are sustainable, ecofriendly, sensitive to sociocultural issues in the community, and economically feasible. Second, ecotourism functions as one of the means to create quality tourism experiences and enhance knowledge about nature, historical heritages, and culture. Third, ecotourism serves as a media to boost local economy and create funding mechanism for conserving biodiversity and preserving culture. Fourth, ecotourism raises the awareness of operators and visitors alike about the standards of sanitation and health in tourism-as well as about the conservation of natural resources, culture, and values of tradition knowledge in the community. These four key points have not 
been realized due to the lack of human resources.

Another weakness is that online based promotion media (digital tourism) has not been conducted earnestly and people still rely on conventional media in the form of leaflets and booklets. At a glance, it may be difficult to understand that in the current digital era there is still a lack of digital technology utilization. However, according to an informant, this is a result of low human resource capacity and lack of promotional budget, and promotional matters are handed over to business actors from outside of the region. Subsequently, community participation in ecotourism development within the island area remains low. Such conditions, as stated by Sari (2017), implies that tourism has not come into contact with the fabrics of Kapota's social life, and residents are neither involved directly nor indirectly since they do not have access to information about tourism and ways of marketing their tourism potentials to the wider public.

\section{c. Opportunity}

The opportunity for ecotourism development is quite significant, which is not unlike the central government's support to the development of island areas. Strong policy support is one of the determining factors in tourism development (Jenkins, 2015). As of current, tourism development http://ojs.unud.ac.id/index.php/eot programs from the central government have reached the Island of Kapota. Among them are provided by the Ministry of Tourism and Creative Economy (Kemenparekraf), such as the construction of the wooden bridge surrounding Lake Tailaronto'oge spanning for $\pm 1 \mathrm{~km}$, assistance in preparing Wakatobi Regency's Rural Area Development Plan (Rencana Pembangunan Kawasan Perdesaan RPKP) with Kapota Island as its locus (2018), and the development of the island's traditional market area in 2019 by the Ministry of Villages and Development of Disadvantaged Regions, and Transmigration (Kemendesa). Moreover, the Ministry of Public Works and Public Housing (Kemen PUPR) had also constructed roads on the island to facilitate the flow of goods and people. Another opportunity refers to the consequences brought about by the establishment of Wakatobi as one of the National Tourism Strategic Areas and one of the 10 National Priority Tourism Destinations.

Furthermore, another opportunity is the trend of the global and national ecotourism market. At the global level, the growth of the ecotourism market has been recorded to be far higher than the entire tourism market. Based on an analysis by The International Ecotourism Society (Damanik and Weber, 2006), the growth of the ecotourism market is approximately 
between 10-30 percent per annum. Nationally speaking, foreign tourist visitations to conservation areas (where ecotourism is applied) in Indonesia continue to climb in the 2015-2019 period, which recorded as many as 2.059 million visitors. This is also the case for the number of domestic tourists visiting conservation sites, which also continued to rise during the 2015-2019 period, totaling as many as 31.866 million visitors (KLHK, 2019). These numbers indicate that ecotourism is predicted to be a highly prospective tourism market in the future.

\section{d. Threats}

Threats may come from competing similar type of ecotourism destinations that have good quality, attractions, and services. Another threat is the advent of external human resources that may be more competent and professional in the field of ecotourism business/services as they may gradually replace local human resources. In addition, there are also issues relating to environmental degradation caused by abrasion, development activities, and conflict of interests between conservation and utilization for ecotourism development. It is as mentioned by Informant 1 in the following passage.
"The potential for coastal abrasion disasters has also increased due to rampant sand mining. That is done by people from here and outside [the island]. The impacts are starting to be felt [...], toppled coconut palm trees on the shores, collapsed roads. If this is ignored, the tourism area status is gone .... It will be more difficult to protect the environment around here".

Another threat that needs to be anticipated is potential conflicts concerning the excessive utilization of natural resources that will clash with conservation efforts conducted by the government.

The elaborations above are subsequently arranged into a matrix pertaining to SWOT analysis on ecotourism development. The SWOT analysis matrix is presented in its entirety in Table 2 below. 
Table 2. Kapota Island Ecotourism Development SWOT Analysis Matrix

\begin{tabular}{|c|c|c|}
\hline$\bigvee^{\text {Eksternal }}$ & \begin{tabular}{ll}
\multicolumn{1}{c}{ Strengths-S } \\
- Various ecotourism attractions \\
based on nature, culture, \\
historical heritages, culinary \\
treats, and crafts (S1) \\
- $\quad \begin{array}{l}\text { Relatively pristine (natural) } \\
\text { environment (S2) }\end{array}$ \\
- Solid support by regional \\
government (S3) \\
- Solid support by Kapota \\
customary institution for \\
ecotourism development (S4) \\
- Hospitality of Kapota community \\
(S5) \\
Easy access from regional capital \\
along with boats and harbor \\
facilities (S6)
\end{tabular} & \begin{tabular}{ll}
\multicolumn{1}{c}{ Weaknesses-W } \\
- & Lack of public facilities and \\
infrastructure in the area (W1) \\
- \\
Lack of ecotourism facilities in \\
the area (W2) \\
- $\quad$ Lack of competent \\
organization and human \\
resources (W3) \\
- Lack of infrastructure \\
development fund (W4) \\
- Lack of digital based (online) \\
promotion media (W5) \\
- Low local community \\
participation (W6) \\
Lack of maintenance to \\
ecotourism facilities (W7)
\end{tabular} \\
\hline \begin{tabular}{ll} 
& \multicolumn{1}{c}{ Opportunities-O } \\
- & Program/policy support \\
from central government \\
(Kemenparekraf, Kemen \\
PUPR, Kemendesa, and \\
KLHK) $(\mathrm{O} 1)$ \\
- $\quad$ Establishment of \\
Wakatobi as a National \\
Tourism Strategic Area \\
(KSPN) and one of the \\
10 National Priority \\
Destinations $(\mathrm{O} 2)$ \\
National and global \\
ecotourism market trend \\
remains open (O3)
\end{tabular} & 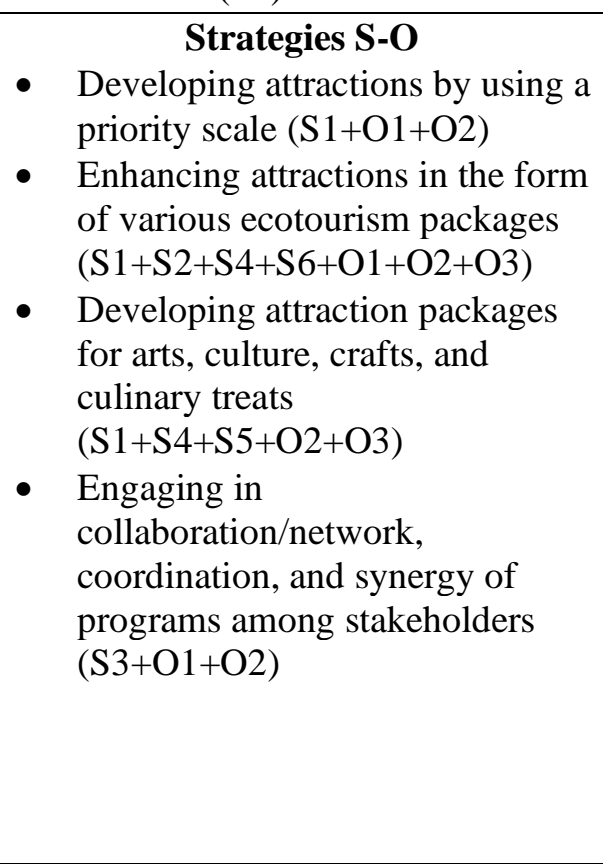 & \begin{tabular}{ll} 
& \multicolumn{1}{c}{ Strategies W-O } \\
- & Improving public facilities and \\
infrastructure in the area \\
(W1+W3+O1+O2) \\
- $\quad$ Improving tourism facilities in \\
the area (W2+O1+O2) \\
- Building capacity of local \\
human resources through \\
trainings, internships, and \\
comparative studies \\
(W3+O1+O2) \\
- Improving tourism promotion \\
through online media (digital \\
tourism) (W5+O1+O2) \\
Raising public awareness \\
through the Tourism \\
Awareness and Seven \\
Enchantment programs \\
(W7+O1+O2)
\end{tabular} \\
\hline $\begin{array}{l}\text { - Threats-T } \\
\text { - New competing } \\
\text { ecotourism attractions } \\
\text { with better quality of } \\
\text { service (T1) } \\
\text { - Environmental } \\
\text { degradation due to } \\
\text { abrasion and } \\
\text { development activities } \\
\text { (T2) } \\
\text { - Conflict of interests } \\
\text { between conservation } \\
\text { and utilization by the } \\
\text { community (T3) } \\
\text { - Pandemic (T4) }\end{array}$ & $\begin{array}{l}\text { Strategies S-T } \\
\text { - } \quad \text { Creating attraction products that } \\
\text { differ from destinations in other } \\
\text { regions ( } \mathrm{S} 1+\mathrm{S} 2+\mathrm{T} 1) \\
\text { - } \\
\text { Encouraging green activities and } \\
\text { tourism awareness campaigns } \\
\text { continuously }(\mathrm{S} 2+\mathrm{S} 4+\mathrm{T} 2) \\
\text { - Encouraging collaboration } \\
\text { between local communities and } \\
\text { the government }(\mathrm{S} 3+\mathrm{S} 4+\mathrm{S} 5+\mathrm{T} 3)\end{array}$ & $\begin{array}{l}\text { Strategies W-T } \\
\text { - } \quad \text { Improving the quality and } \\
\text { uniqueness of attractions to } \\
\text { respond to competition } \\
\text { between existing destinations } \\
\text { (W4+T1) } \\
\text { - Monitoring and maintaining } \\
\text { facilities constructed in } \\
\text { ecotourism attractions } \\
\text { (W7+T2) }\end{array}$ \\
\hline
\end{tabular}

Source: Analysis Results, 2018

http://ojs.unud.ac.id/index.php/eot 
Ecotourism Development Strategies

Kapota Island's ecotourism development strategies refer to the SWOT analysis matrix by producing 4 (four) alternatives, namely: (a) strategy SO (a strategy that utilizes strengths to take advantage of opportunities); (b) strategy WO (a strategy that minimizes weaknesses to take advantage of opportunities); (c) strategy ST (a strategy that utilizes strengths to address threats); and (d) strategy WT (a strategy that minimizes weaknesses and prevents threats).

a. Strategy SO (Strengths and Opportunities), which is a strategy that optimizes strengths (S) to take advantage of opportunities (O), includes:

1. Developing attractions by using a priority scale, namely Tailaronto'oge Lake and Oa Wolio Beach. The variety of attractions, totaling more or less 35 spots, is relatively difficult to develop in unison due to lack of resources. Hence, a priority scale needs to be determined. Tailaronto'oge Lake and Oa Wolio Beach are considered as potential spots for development due to easy access from Kapota harbor, existing tourism facilities like wooden bridge along the lake side, gazebo, and the fact that these two spots function as destinations for tourists when visiting Kapota.

2. Packaging these attractions by preparing various ecotourism packages.

3. Developing attraction packages for arts, culture, crafts, and culinary treats.

4. Engaging in collaboration/network, coordination, and synergy of programs among stakeholders.

b. Strategy WO (Weaknesses and Opportunities), which is a strategy that minimizes weaknesses (W) to take advantage of opportunities (O), includes:

1. Improving public facilities and infrastructure in the area such as access to areas around the island, clean water, electricity, waste management.

2. Improving tourism facilities in the area, such as TIC, restaurants, lodging/homestay, snorkeling and diving equipment.

3. Building human resource capacity of local business actors and operators through trainings, internships, and comparative studies. Relevant skill trainings for the community concerning issues such as food packaging, crafts, homestay, souvenirs, foreign language, tour guide, arts and e-ISSN: 2407-392X. p-ISSN: 2541-0857 
culture, as well as Search and Rescue (SAR). In terms of the Kapota Sarong (Leja) product, it should be directed to: (a) maintain cheap and easy to acquire supply of raw materials; (b) conduct product diversification; (c) develop manufacturing technology; (d) improve institutional organization (cooperatives or weavers group); (e) enhance marketing efforts; (f) maintain business continuity through regeneration by resuming the business (provide education concerning the local community's love of weaving); and (g) be given government support in the form of education and training, assistance in providing production tools, capital loan, participation in exhibitions, patent protection (particularly for Leja sarong weaving product), and fostering the community's love of craft products.

4. Improving tourism promotion through online media (digital tourism). Other than promotion via digital media, the following stage is the need to facilitate collaboration with travel agents, both domestic and foreign.

5. Raising public awareness through the Tourism Awareness and Seven Enchantment (Safe, Orderly, Clean,
Cool, Beautiful, Friendly, and Memorable) programs.

c. Strategy ST (Strengths and Threats), which is a strategy that utilizes strengths (S) to address threats (T), includes:

1. Creating attraction products that differ from destinations in other regions.

2. Encouraging greening activities and tourism awareness campaigns continuously to both local communities and visitors.

3. Encouraging conservation partnerships between the government and local communities. Reinforcing the concept and branding of Kapota ecotourismdevelopment that is in harmony with the seven principles of ecotourism. In this context, Kapota Island ecotourism needs to be guided properly so that its development is in line or does not impede environmental conservation efforts as well as have a positive impact in boosting local economy.

d. Strategy WT (Weaknesses and Threats), which is a strategy that minimizes weaknesses (W) and prevents threats $(\mathrm{T})$, includes:

1. Improving the quality and uniqueness of attractions to face 
competition among existing ecotourism destinations.

2. Monitoring and maintaining facilities that have been constructed in ecotourism attractions, such as Tailaronto'oge Lake, and Dewata/Bat Cave.

\section{CONCLUSION AND RECOMMENDATION}

The current study revealed that Kapota Island has various attractions as an ecotourism destination. These attractions are in the form of nature, culture, and even historical heritages distributed throughout the island. Ecotourism development in Kapota, undoubtedly, remains weak, and it has yet to touch upon the fabrics of social life. Infrastructure support, public facilities, and tourism facilities are still insufficient for tourists. Such lacking conditions are considered as one of the challenges/weaknesses in the efforts of developing ecotourism. An opportunity that may be developed by local communities is to encourage the involvement of strategic ecotourism business units as a way to empower people in the region.

The threat of environmental degradation as a result of development on the island must be anticipated from the onset since it may threaten the island's coastal community's socio-economic and ecological continuity in the future. The strategies for ecotourism development in Kapota Island are achieved by employing an optimized offensive strategy, namely by utilizing all existing strengths and opportunities. Ecotourism development should be aligned with the community's economic, cultural, and social conditions, and it should not clash with the conservation efforts that have been conducted. Furthermore, strong commitment and engagement of stakeholders are key in the development of Kapota Island as an ecotourism destination in Wakatobi Regency, in particular, and Southeast Sulawesi, in general.

The recommendation, based on the study results, is to suggest measures and efforts to accelerate Kapota Island ecotourism development. First, attractions should be developed using a priority scale. Tailaronto'oge Lake is considered as the highest priority for development with the support of cultural attractions. Second, concrete activity/program support provided by all Pentahelix elements, namely the government, private sector, scholars, communities, and media.

Third, public infrastructure, public facilities, and tourism facilities in the area, such as clean water, electricity, waste management, accommodation (lodging and restaurant), and other facilities should be improved. Fourth, opportunities and e-ISSN: 2407-392X. p-ISSN: 2541-0857 
support should be given to Tourism Awareness Group operators and craft business actors to participate in internship or training activities periodically in more developed ecotourism destinations or craft tourism villages in order to enhance their capacity. Fifth, support should be given to raise public awareness through actual actions, such as environmental awareness and tourism awareness campaigns, green activities, and beach clean-up events. Sixth, there is a need for support in developing online-media-based promotion and marketing network across various sectors and actors.

\section{ACKNOWLEDGEMENT}

We would like to convey our gratitude to the Ministry of Villages, Development of Disadvantaged Regions, and Transmigration of the Republic of Indonesia that have funded the current research through a self-managed collaboration with the Center for Tourism Studies, UGM. We would also like to send our appreciation to our colleagues, the team from the Planning, Research, and Development Agency (Bappelitbang), the Village Community Empowerment Office, and the Tourism Office of Wakatobi Regency, along with Mr. Suhaeri as Kapota Island's local champion.

\section{REFERENCES}

Afiyanti, Y. 2008. Focus Group Discussion sebagai Metode Pengumpulan Data Penelitian Kualitatif. Jurnal Keperawatan Indonesia, 12(1), 5862.

Arida, I. N. S., and Rohman. 2019. Perencanaan Pariwisata and Keberlanjutan: Potret Perencanaan Pariwisata di Karangasem, Bali. Denpasar: Cakra Media Utama.

Arida, I. N.S., Baiquni, M., Damanik, J., and Ahimsa-Putra, H. S. 2014. Dinamika Ekowisata Tri Ning di Bali: Problematika and Strategi Pengembangan Tiga Tipe Ekowisata di Bali. Kawistara, 4(2), 111-127.

Buckley, R. 2003. Case Studies in Ecotourism. Cambridge: CABI.

Butcher, J. 2007. Ecotourism, NGOs and Development: A critical analysis. London: Routledge.

Ceballos-Lascurain, H. 1996. Tourism, Ecotourism, and Protected Areas: The State of Nature-based Tourism Around the World and Guidelines for Its Development. IUCN: Cambridge. [The World Conservation Union].

Damanik, J and Weber, H.F. 2006. Perencanaan Ekowisata: Dari Teori ke Aplikasi. Yogyakarta: Andi.

Diamantis, D. 1999. The Concept of Ecotourism: Evolution and Trends. Current Issues in Tourism, 2(2\&3), 93-122.

Dinas Pariwisata Kabupaten Wakatobi. 2015. Masterplan Pariwisata Kabupaten Wakatobi 2016-2026. Wakatobi: Dinaspar. 
Dowling, R.K and Fennell, D.A. 2003. "The Context of Ecotourism Policy and Planning". In Fennell, D.A and Dowling, R.K (ed.), Ecotourism Policy and Planning (pp. 1-20). Oxon: CABI Publishing.

Eusébio, C., Vieira, A. L., Lima, S. 2018. Place attachment, host-tourist interactions, and residents' attitudes towards tourism development: The case of Boa Vista Island in Cape Verde. Journal Sustainable Tourism, 26, 890-909.

Fandeli, C and Mukhlison. 2000. Pengusahaan Ekowisata. Yogyakarta: Kerja sama Fakultas Kehutanan UGM, Pustaka Pelajar, and Unit Konservasi Sumber Daya Alam DIY.

Fennel, D. A. 2002. Ecotourism Programme Planning. Wallingford, UK: CABI Publishing.

Hawkins, D.E and Lamoureux, K. 2001. "Global growth and magnitude of ecotourism". In D.B. Weaver (ed.), The Encyclopedia of Ecotourism (pp. 63-72). UK: CABI Publishing.

Hirotsune, K. 2011. "Tourism, Sustainable Development and Ecotourism in Developing Countries." Paper presented on ANDA International Conference, Nagoya University, Japan, March 5-7.

International Ecotourism Society. 2005. Research (statistics and fact sheets), available at http://www.ecotourism.org (accessed Juni 29, 2020).

Jenkins, C. L. 2015. Tourism Policy and planning for developing countries: some critical issues. Journal of Tourism and Recreation Research, 40(2), 144-156.
Kementerian Desa, Pembangunan Daerah Tertinggal, and Transmigrasi. 2018. Rencana Pembangunan Kawasan Perdesaan (RPKP) Kabupaten Wakatobi. Laporan Akhir. Jakarta.

Khalid, S. Ahmad, M. S., Ramayah, T., Hwang, J., and Kim, I. 2019. Community Empowerment and Sustainable Tourism Development: The Mediating Role of Community Support for Tourism. Sustainability, 11, 6248; doi:10.3390/su11226248.

KLHK (Kementerian Lingkungan Hidup and Kehutanan). 2019. Laporan Kinerja Direktorat Jenderal Konservasi Sumber Daya Alam and Ekosistem 2019. Jakarta: KLHK.

Marzouki, M., Froger, G., and Ballet, J. 2012. Ecotourism versus Mass Tourism. A Comparison of Environmental Impacts Based on Ecological Footprint Analysis. Sustainability, 4, 123-140. doi:10.3390/su4010123.

Muhtadi, D. 26 Juli 2012. UNESCO Tetapkan Laut Wakatobi Sebagai Cagar Biosfir https://sains.kompas.com/read/2012/ 07/26/13111438/UNESCO.Tetapkan .Laut.Wakatobi.Sebagai.Cagar.Biosfi r.

Namugenyia, C., Nimmagaddab, S. L., and Reinersc, T. 2019. Design of a SWOT Analysis Model and its Evaluation in Diverse Digital Business Ecosystem Contexts. Procedia Computer Science 159, 1145-1154

Nasrun. 2016. Partisipasi Masyarakat dalam Pengelolaan Ekowisata Bahari di Pulau Kapota Taman Nasional Wakatobi. Tesis. Yogyakarta: Magister Kajian Pariwisata Universitas Gadjah Mada. 
Nazir, M. 2011. Metode Penelitian. Jakarta: Ghalia Indonesia.

Nyumba, T. O., Wilson, K., Derrick, C., and Mukherjee, N. 2018. The use of focus group discussion methodology: Insights from two decades of application in conservation. Methods in Ecology and Evolution, 9, 20-32.

Panos Media Briefing. 1995. Ecotourism: Paradise gained, or paradise lost? London: Panos.

Rafika. 2011. Perencanaan Jalur Interpretasi Alam di Pulau Kapota, Taman Nasional Wakatobi. Skripsi. Institut Pertanian Bogor. Bogor.

Republik Indonesia. 2009. UnandgUnandg Republik Indonesia Nomor 10 Tahun 2009 tentang Kepariwisataan. Jakarta.

Republik Indonesia. 2011. Peraturan Pemerintah Nomor 50 Tahun 2011 tentang Rencana Induk Pembangunan Pariwisata Nasional (Ripparnas). Jakarta.

Sadikin, P. N., Arifin, H. S., Pramudya, B., and Mulatsih, S. 2017. Carrying capacity to preserve biodiversity on ecotourism in Mount Rinjani National Park, Indonesia. Biodiversitas, 18(3), 978-989. DOI: 10.13057/biodiv/d180316.

Salazar, N. B. 2007. Small is Successful: The Lure of Small-Scale Tourism Development and Transnational Networking, pp. 396-420. In: A. Raj (Ed.), Sustainability Profitability and Successful Tourism. New Delhi: Kanishka Publishers.

Sari, I. P. 2017. Konflik Kepentingan dalam Pengembangan Pariwisata: Kasus Pulau Kapota, Wakatobi, Sulawesi Tenggara. Tsaqofah \& Tarikh, 2(1): 29-38.

http://ojs.unud.ac.id/index.php/eot
Scheyvens, R. 1999. Ecotourism and the employment of local communities. Tourism Management, 20, 245-49.

Snyman, S. 2017. The role of private sector ecotourism in local socio-economic development in southern Africa. Journal of Ecotourism, 16(3), 247268.

Stein, T.V. 2004. Things to know about offering naturebased tourism on private forestlands in Florida. Florida Forests, 8(1), 6-10.

Suhandi, A. S. 2020. Adaptasi Pengelolaan Ekowisata Pasca Covid 19. Makalah 25 Tahun Indecon. Jakarta.

Sumarno, E. 2016. Pulau Kapota The Small Hiden Paradise. September 2016 (https://foresteract.com/pulaukapota-the-small-hidden-paradise), diakses 21 Mei 2020.

Supriatna, J. 2008. Melestarikan Alam Indonesia. Jakarta: Yayasan Obor Indonesia.

Wahab, S. 1989. Manajemen Kepariwisataan. Pradnya Paramita. Jakarta

Wallace, G. N and Pierce, S.M. 1996. An Evaluation of Ecotourism in Amazonas, Brazil. Annal of Tourism Research, 23(4), 843-873.

Western, D. 1997. "Memberi Batasan Tentang Ekoturisme." In: K. Lindberg and D. E. Hawkins (Eds.), Ekoturisme: Petunjuk untuk Perencana and Pengelola (trnsl.). Jakarta. PACT and ALAMI.

World Travel and Tourism Council. 2004. Tourism Satellite Accounting 2004: Executive Summary. On WWW at (http://www.wttc.org/2004tsa/PDF/E xecutive\%20Summary.pdf). Accessed April 2005.

e-ISSN: 2407-392X. p-ISSN: 2541-0857 
WWF. 2017. Satu Dekade Pengelolaan Taman Nasional Wakatobi: Keberhasilan and Tantangan Konservasi Laut. Jakarta: WWF.

Yulius., Novianti, N., Arifin, T., Salim, H. L., Ramdhan, M., and Purbani, D. 2015. Distribusi Spasial Terumbu Karang di Perairan Pulau WangiWangi, Wakatobi. Jurnal Ilmu and Teknologi Kelautan Tropis, 7(1), 5969. 